\title{
The Implementation of Brand Awareness Strategies to Attract New Customer to The Company
}

\author{
Khairiah Hussin, Sanil S Hishan
}

To Link this Article: http://dx.doi.org/10.6007/IJARBSS/v12-i1/12178

DOI:10.6007/IJARBSS/v12-i1/12178

Received: 06 November 2021, Revised: 11 December 2021, Accepted: 24 December 2021

Published Online: 21 January 2022

In-Text Citation: (Hussin \& Hishan, 2022)

To Cite this Article: Hussin, K., \& Hishan, S. S. (2022). The Implementation of Brand Awareness Strategies to Attract New Customer to The Company. International Journal of Academic Research in Business and Social Sciences, 12(1), 1534-1552.

\section{Copyright: (c) 2022 The Author(s)}

Published by Human Resource Management Academic Research Society (www.hrmars.com)

This article is published under the Creative Commons Attribution (CC BY 4.0) license. Anyone may reproduce, distribute, translate and create derivative works of this article (for both commercial and non0-commercial purposes), subject to full attribution to the original publication and authors. The full terms of this license may be seen at: http://creativecommons.org/licences/by/4.0/legalcode

\section{Vol. 12, No. 1, 2022, Pg. $1534-1552$}

Full Terms \& Conditions of access and use can be found at http://hrmars.com/index.php/pages/detail/publication-ethics 


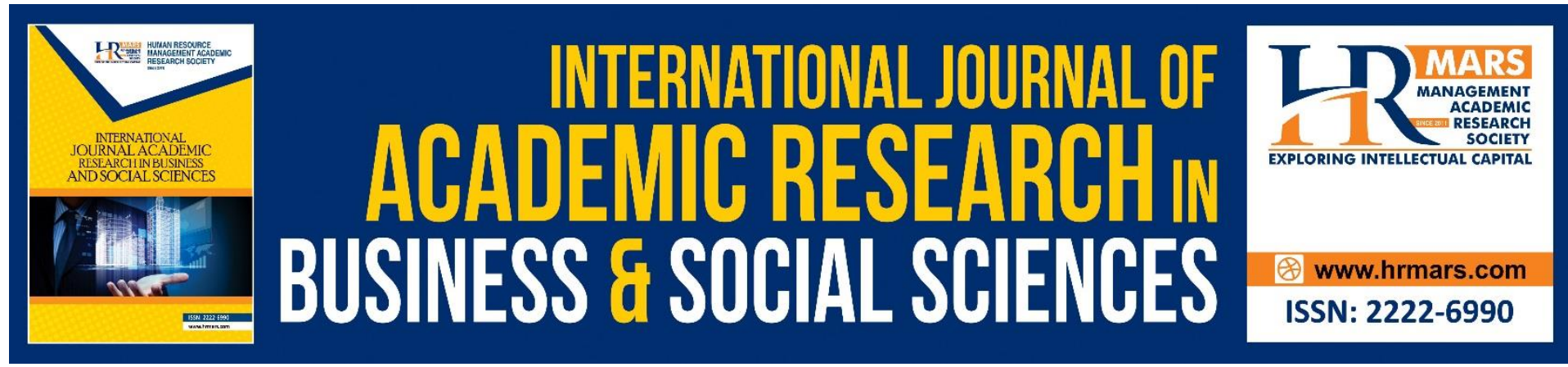

\title{
The Implementation of Brand Awareness Strategies to Attract New Customer to The Company
}

\author{
Khairiah Hussin, Sanil S Hishan \\ Azman Hashim International Business School, Univeresity Teknologi Malaysia (UTM), Johor \\ Bahru, Malaysia.
}

\begin{abstract}
The purpose of this paper is to measure the implementation of brand awareness strategies to attract new customer into the company. The study aims 'To identify the issues related to the brand awareness of the company's products among its potential and existing customers, to implement the intervention to increase the brand awareness of the company's products and 'To recommend marketing plan to increase brand awareness of the company's products. The mixed method is chosen throughout the process. This research study was carried out and finished within three semesters. The interview and the survey are performed to collect the results. The study was divided into two stages, Qualitative study was conducted for cycle 1 only, to identify the problems and to propose the interventions. The initial meeting to classify the issue of diagnosis and to acquire supporting documentation is followed by another interview session to assess the intervention that is run by the company and another interview session has been conducted with the existing customer which purposely to share the issues, awareness, and experience with the company's product and service. In this qualitative study, thematic analysis approach was used for data analysis using NVivo software. There are three interventions that have been made by the company; 'To increase the brand awareness by using social media platform', and 'To create new uniform design with the company logo for employees. Next, in second stage, Quantitative analysis was used to measure the effectiveness of the intervention in cycle 1 and cycle 2 . In the Cycle 1, survey questionnaires were distributed by online to 60 new potential customers to participate in the pre-survey towards the company brand to measure 'Awareness on product and service of company and Awareness on product and service of company in social media. After that, the remain customer from the pre-survey were participated in the post-survey to measure 'Awareness on product and service of company, Awareness on product and service of company in social media and Implementation of the intervention'. A descriptive and T-test analysis was carried out using Statistical Package for the Social Sciences (SPSS) software. Consequently, the triangulation approach was used to combine all quantitative and qualitative results to produce a reliable outcome. Based on the observation, there is a difference between the mean and standard deviation ratings for both before and after implementing the intervention. Hence, the null hypothesis was rejected, and the result showed that there is a difference between before and after the intervention implementation. In Cycle 2 Action
\end{abstract}


Research, Quantitative method was used in this analysis. In this cycle 2, an online survey questionnaire already been provided to 100 of customers. A descriptive and T-test analysis has been carried out using Statistical Package for the Social Sciences (SPSS) software. New intervention has been implemented in Cycle 2; 'To increase the awareness by using Facebook Page' and 'To appoint a marketing consultant'. There was positive improvement before and after intervention implementation, indicating that all three of our objectives were successfully achieved. Nevertheless, the company's social media participation score remained comparatively modest. As a result, new future intervention should be updated based on study outcomes and company preferences.

Keywords: Brand Awareness, Digital Marketing, Social Media Platform, Facebook, Marketing Strategies, Customer Awareness, Consumer Behaviour.

\section{Introductions}

In this globalization era, most agencies and companies implement video media to educate and support their businesses. Video is the most popular medium, since it has motion elements, actual animation, pictures, sound and even several musical elements and called multimedia units. Multimedia is a mix of three elements which is speech, picture and text, the machine and video or multimedia in general. Multimedia is a computer-based program for the display in integrated form of text, images, video, animation, and sound. Multimedia is a combination of visual, audio, graphics and text that can be interactive in an immersive, computer-based production. Whilst visual audio is a combination of two words, meaning sound and visual, meaning an image, that is, the clarification of visual audio is a prop that moving images produce a sound in this regard. It is important for the companies to increase their brand awareness. Advertising is one of the determinants of a company's system marketing success. Branding helps company to develop relationships with company's target audience, which may eventually lead to them becoming devoted consumers. Companies can build a brand that people care about and push their self ahead of competitors who are not taking advantage of this. As we know, especially during the global pandemic of the coronavirus (COVID-19) has resulted in changes to advertising, marketing, promotional, and media spends, forcing businesses and brands to rethink current and future advertising and marketing campaigns in order to maintain a steady stream of income, as well as awareness of consumers' increased anxiety at this time. When the globe was turned upside down by the Covid-19 epidemic, companies were obliged to retain and establish connections with customers. Businesses must now balance the need to generate sales at a moment of acute economic distress with the need to recognise the risks to life and livelihood that have shifted customer priorities and preferences. Companies must be social in order to boost brand awareness. In another word, companies should use social media to build their brand, sell their products, and market them rather than engaging with and co-creating with customers, and, more importantly, offering a platform for customers to connect. The main objective of this action research is to study the implementation of the brand awareness strategies to attract a new customer to the company.

\section{Research Objectives}

- To identify the issues related to the brand awareness of the company's products among its potential and existing customers.

- To implement the intervention to increase the brand awareness of the company's products. 
- To recommend marketing plans to increase brand awareness of the company's products.

\section{Importance of the Proposed Research Theoretical}

The present study makes an important theoretical contribution to the body of information in the field of brand awareness. The research contributes to the vital knowledge in the field of marketing, targeted to brand awareness especially in Malaysian context. As refer to previous literature studies in the field of CSR, the majority of the studies are applied studies, with just a few studies using the Action Research method and as a result, this study fills a gap in the action research literature in the field of brand awareness. The research also adds to the body of knowledge on brand awareness in the audio-visual and multimedia industries.

\section{Practical}

The research helped to raise the company's brand image among new and current customers. By conducting this research can also, assist the company in understanding brand awareness techniques, as the company has agreed to introduce the intervention from Cycle 1 and Cycle 2 and to assist the GG company in increasing their brand awareness.

\section{Literature Review}

Brand awareness is 'The ability of a potential customer to recognize or recall that a brand is a member from a certain product category, to determine a link between the specific product and the brand'. Horsfall et.al (2020), discovered that brand awareness can be defined as a degree of customer familiarity with a brand and is linked to the strength of a brand node or memory trace as reflected in the capacity of customers to remember or identify a brand under various conditions. Brand awareness is related to the ability of a customer to recognize the brand, to associate a brand to a brand name, symbol, or logo. Based on the previous studies, Brand awareness is related to the significance of the brand which makes it possible for customers to be directly identified with the brand in a specific product class Horsfall et.al (2020) Brand awareness is the willingness of potential customers to identify and recognize a brand as part of a specific product segment, and it involves a continued sense of uncertainty as to whether the brand has been recognized previously, such that the buyer believes that the product is the only brand of a certain community. People have, and are conscious of, prior knowledge on who they are, the context of the circumstances, where they are based, as well as the feeling of the place, what time of year it is and what day it is, and also what to do the rest of the day and if at the same time, there is knowledge of everything, the severity varies. People's consciousness is continuously reshaping the form, and what we term awareness is the amount of the individual's knowledge but it's possible to do one thing when peoples are still mindful of several other things (Bornmark et al., 2005). Brand awareness is the ability of the customers to identify or recall a brand, and there is a correlation between the brand and the specific product, but the link does not have to be powerful. Brand awareness is a mechanism from which the brand is only recognised at a stage where customers have put the brand on a higher level that the brand has become the 'top of mind' (Bornmark et al., 2005).

\section{Summary of Literature}

To let customer, identify and recognise a brand is one of the core priorities of brand management. The most critical benefit for companies to raise Brand Awareness is to improve 
the identity of their product and services in the mind of the customers and to affect the customer relationships and decision-making processes in relation to a precise process pertaining to a specific brand. According to Chierici et.al (2019), enhancing Brand Awareness entails establishing a brand's identity in customer's memories and subsequently affecting customer's associations and decision- making process around the particular brand and also by using social media, businesses can exchange real time product impressions and views. Thus, increasing visibility and demand. Other than that, Brand awareness precedes the established equity in the minds of consumers. As stated by Kilei et.al (2016), It is critical for marketing brands to continue developing and implementing successful brand awareness strategies in order to draw and increase customer attention to the company products, thus improving market brand performance. This approach can be successful by consistently approaching customers and developing long- term relationships with them through a twoway conversation using a variety of effective media platforms such as offline communications and social media platforms (Hishan et.al., 2021; Al-Mashhadani, 2021; ). This enables marketers to comprehend the importance of brand awareness through social media platforms, where they can build virtual words and communicate directly with their existing and prospective customers, thus, increasing brand (Ansari et al., 2019).

\section{Relevant Theories and Model AIDA Marketing Model}

The AIDA marketing model was used by the research in the study. Future researchers can use a different model to pursue their studies. The proposed model is based on a communication theory that stands for 'Attention, Interest, Desire and Action' (Faladhin \& Martina, 2020). According to Ghirvu (2013), Marketers must take special steps at each of the process's four phases in order to achieve the desired outcome. These moves are intended to chart the customer's cognitive route. Thusly, the four steps of acquisition outline below:

- $\quad$ Attention: The advertisement should be promoted by the company in such a way that the buyer is made aware of its presence.

- Interest: Interest is manifested when a customer communicates consciously in relation to a product or service of which she or he is aware.

- Desire: Marketers may use advertisements to generate demand for a specific product or service

- Action: marketers rely on convincing the customer to complete the whole cognitive loop with an actual acquisition, with the concrete activity of purchasing the product or service.

\section{Level of Brand Awareness}

Brand awareness is the willingness of the customers to identify and recognise a brand as part of a specific product segment, and it involves a continued sense of uncertainty as to whether that brand has been recognised previously, such that the buyer believes that the product is the only brand of a certain community. It is divided into four levels of brand awareness which include unawareness of brand, brand recognition, brand recall and top of mind. From the lowest level of the pyramid is 'Unaware of brand'. It means the product and service of the company are not recognised where customers are unaware of the company brand. Next, 'Brand recognition' is a minimal level of the brand awareness where it is necessary for the customers to select a brand at the time of purchase. It is also known as brand levels of aided recall (Hansel et.al., 2016). Followed by the second highest pyramid level. 'Brand Recall', this 
is a re- branding of the brand without any help (Pandjaitan, 2018). Brand recall or unaided brand recall when customers do not have to be helped to remember the brand (Hansel et.al., 2016). It is more difficult to calculate unaided brand awareness than assisted brand recognition. Aid for the identification of helped brands can include posters, photographs, commercials, banners or social media (Hansel et.al., 2016). Finally, the highest level of this pyramid is the 'Top of Mind'. This is the brand that is remembered for the first time as people are asked about the type of product that can be unexpectedly or spontaneously recalled without any help (Pandjaitan, 2018; Akhtar et.al, 2021).

\section{Problem Diagnosis}

\section{C Model by Kenichi Ohmae}

Customers are the backbone of every plan of Ohmae. The main aim is that business owners need to develop interest toward creating bonds with their customers. In the long run, a company such as GG company, also known as a service-based company, will continuously grow its customer's relationship and at the same time be beneficial towards the company. According to the company, the main target customers are generally well trained and have a decent career and a steady income salary. There could be a new established college and a successful company that are seeking for service provided by GG company. In addition, the majority of GG's customers come from the power of "word of mouth" or known as recommendation from their friends and their relatives. I discovered that GG company constantly and regularly updates on their stock, promotion or upcoming event via mail and sends directly to the customer that joins the subscription mail. They prefer to use direct marketing because they are more comfortable using the catalogue instead of the used Ecatalog where they can just broadcast the email to customers that join their online subscription. The major competitors of GG company are PSS company, which focus on providing more than just sales and support efficiency, and their staff is well trained with deep understanding of AV systems and experience in marketing services. competitors are AVSI company. It is a new established company compared to GG company. They have been established for over 10 years. AVSI company provides a wide array of AV products. They offer audio visual and lighting assistance to the business sector, conference managers, construction firms, any trade shows, and conferences. They also collaborate side by side with their partners to provide the most robust solutions possible to ensure a successful event. While solid financial skills, market value, years of experience and customer's information are one of the great benefits to large companies as these offer the same product and service to customers all-around of the places. It is hard for them to sell personalized products and services based on their customer's taste and preference. Next, corporation. GG company created an official website for their customers. They provide pictures of the products and services that are included with the price. Unfortunately, the customer can only view the website without purchasing the products and services. There is no payment gateway provided in the websites. It is important to include a payment gateway as the function is accepting all purchases on one site and accelerating conversions everywhere in the world. Make references on the problem statement of the company, the shortage of skilled workers is a main problem facing GG company itself. Lack of experienced workers especially in the marketing field. Through that, they used marketing strategies without any knowledge and experienced workers that an organization needs and have an additional outlook on internal issues. Lack of experienced workers especially in the marketing field. Through that, they used marketing strategies without any knowledge and experienced workers that an organization needs and have an 
additional outlook on internal issues. They may also lack a new viewpoint on customers or marketing campaigns which encourage an organization to concentrate on product creation and overall operations.

\section{Hypothesis}

The hypothesis implemented in this intervention. The hypothesis is a proportion, state or principle that is briefly assumed to be valid and perhaps without any guarantee of logical consequence to be drawn and then the outcomes of the study carried out the result. This research suggest GG company to increase the brand awareness by using social media platform and create a new uniforms design with the company logo for employees and also recommend the marketing plan by hiring the marketing consultant for GG company. The Table 1 shows the list of:

Table 1: Tested Hypothesis

\begin{tabular}{llc}
\hline \multicolumn{1}{c}{ Hypothesis } & \multicolumn{1}{c}{ Description } & Hypothesis supported \\
\hline $\begin{array}{l}\text { Company's issues of the } \\
\text { products among its } \\
\text { potential and existing } \\
\text { customers' }\end{array}$ & $\begin{array}{l}\text { Recognize the company's } \\
\text { issues before implement the } \\
\text { intervention in the company }\end{array}$ \\
$\begin{array}{l}\text { Increase the brand } \\
\text { awareness of the company's } \\
\text { products }\end{array}$ & $\begin{array}{l}\text { Improve the brand } \\
\text { awareness of the company } \\
\text { to keep the company brand } \\
\text { top of mind among current } \\
\text { \& potential customers. }\end{array}$ & Accepted \\
Marketing plan & $\begin{array}{l}\text { Hiring the marketing } \\
\text { consultant to guide the } \\
\text { company by using the } \\
\text { effective marketing plan }\end{array}$ & Accepted \\
\hline
\end{tabular}

\section{Methodology}

\section{Philosophy of Research}

Action research is a participation, collaborative process dealing with creating realistic expertise in the development of decent human goals, based on participation viewpoint (Johnson, 2012). Research is impacted by philosophical notions even when they are rarely defined explicitly (Johnson, 2012). The research relies primarily on a mixed method approach. The mixed method approach allowed researchers such as me to investigate the study through qualitative and quantitative approaches. One-to-one interview or a face to face through video call interview session was performed to identify the diagnosis of the issues and to assess the action carried out within the company.

In addition, the online survey questionnaire was circulated to determine the efficacy of the action strategy in the company through an interview session and online survey, the researcher found out to be more motivated to develop an understanding of the study and scope. Analysis would become more systematic and comprehensive than research based exclusively on either a qualitative or quantitative method. Compare, then the qualitative and 
quantitative results generated from the respondents and findings on supporting materials to determine the efficacy of the intervention. The combination of qualitative and quantitative data may often contribute to clashes in the philosophical principles underlying each strategy, and thus suggestions have been made for triangulation to be carried out from a pragmatic or subtle practical approach (Sarah et.al., 2016).

\section{Research Role}

As a responsible researcher, I proposed an intervention plan in this research, which is to improve brand awareness among the customers. GG company also can appoint a new marketing consultant to increase their brand awareness. Other than that, based on their existing customer's opinion, GG company needs to provide uniforms for employees or other merchandise so that people are more aware of the company's brand. In this globalization era, people are more exposed to social media platforms. GG company should increase their brand awareness through social media platforms.

\section{Research Design}

The problem is defined at the initial stage and a decision is made to address the problems. Both qualitative and quantitative data have been compiled. The interview was held at the initial stage where the issues were explained. The previous analysis, carried out by other researchers, would include a hypothesis to solve a similar problem. Recommendation and consequences would only be given after studying the previous study. A triangulation protocol may also improve the relevance of the result and determine whether the evidence agrees, complements or contradicts each other. Some caution is recommended when doing triangulation due to its possible difficulty. One guideline indicates that researchers should have necessary skills in qualitative and quantitative approaches to ensure that the data is correctly managed.

\section{Validity}

In this research, the qualitative data which is the interview with the top management and interview with the existing customers to identify the issues of the brand awareness of the product and service. While for the quantitative data in Cycle 1, which is online survey questionnaire taken from new customers and in the Cycle 2, the same online survey questionnaire taken from both new and existing customers to measure the awareness of the product and service of the company. The data for the qualitative was organized into a few themes through thematic analysis. While for the quantitative data have been used the chart comparison with mean and standard deviation data.

\section{Data Analysis Method (Mixed Method) Qualitative (Cycle 1)}

Firstly, for AR Cycle 1, I have started with qualitative data collection. In this qualitative technique, the interview method is chosen which is described as a conversation between two or more participants. Structured interviews were performed by utilizing the similar questions which were used in the survey questionnaire. Structured interviews can summarize the outcome and the response. Face to face interview sessions with the top management of the company had been conducted at a café and another interview via video call with the existing customer. Nine (9) questions were asked to the top management and eleven (11) questions 
were asked to the existing customer. Both of the questions were analysed by using NVIVO software to identify the problem issues.

\section{Quantitative (Cycle 1 and Cycle 2)}

Quantitative research aims to analyse the relation between the variables to explain the phenomenon. Quantitative analysis method is also rigid, in which attention is paid to scientific research methods where data are used numerically to collect information in fact (Majid and Sarhang, 2019). The online questionnaire for the accuracy of the result has been obtained in this research. The questionnaires were distributed by using online-based survey tools such as Google form. The question of the survey has been adapted from the previous study (Kilei et.al, 2016). Firstly, for the AR Cycle 1, two questionnaires are created. Sixty (60) new potential customers participated in both questionnaires.

First is the Pre-Survey questionnaire. In Section A, all information from the potential customers such as age, gender and their occupation. Likert scale questions are used in both Section B and Section C, where potential buyers are asked to measure the scale from 1 to 5 to indicate their choice. For example, 1=Strongly Disagree, 2=Disagree, 3=Doubtful, 4=Agree, $5=$ Strongly Agree. Total of five-point Likert scale is less of an option for the potential customers to prevent misunderstanding. Although Section B sought information on the awareness on the product and service of the company which is adapted from (Kilei et.al, 2016). Section $C$ is adapted from Jumiati et.al (2015) that contains awareness on product and service of the company in social media. The quantitative analysis has been analysed using SPSS tools.

After the company implied the intervention, Post Survey questionnaires were created. In Section $A$ until Section $C$ remaining the same content as the pre-survey questionnaires. In Section $D$, implementation on intervention questions were asked to the respondent. Followed by AR Cycle 2, the previous post survey questionnaires were used. It is used to measure the awareness of new potential customers and existing customers toward the product and service of the company after the interventions are implemented. Hundred (100) survey questionnaire were asked to both participant. The post survey questionnaire was analyse using T-test.

\section{Qualitative Analysis}

Thematic Analysis for Problem Identification in GG company. Table 2 shows the interview questions for the top management and for the existing customers. While for Table 3 below shows the codes and summary from the data. 
Table 2) Interview questions

\begin{tabular}{|l|l|}
\hline \multicolumn{1}{|c|}{ Top management } & \multicolumn{1}{|c|}{ Existing Customers } \\
\hline $\begin{array}{l}\text { 1. Can you briefly explain about your } \\
\text { company }\end{array}$ & $\begin{array}{l}\text { 1. Can you briefly explain about your } \\
\text { company }\end{array}$ \\
\hline $\begin{array}{l}\text { 2. What type of the business form do you } \\
\text { do? }\end{array}$ & 2. Have you purchased the product before? \\
\hline 3.What is the company product and service & $\begin{array}{l}\text { 3. Where have you seen, or you heard about } \\
\text { the company brand? }\end{array}$ \\
\hline $\begin{array}{l}\text { 4. Tell us about your company's greatest } \\
\text { achievement till now? }\end{array}$ & $\begin{array}{l}\text { 4. How long have you used products or } \\
\text { services of the company? }\end{array}$ \\
\hline $\begin{array}{l}\text { 5. What are the major challenges faced by } \\
\text { your company? How did the company } \\
\text { manage these challenges? }\end{array}$ & $\begin{array}{l}\text { 5. How often have you purchased the } \\
\text { products or services of the company? }\end{array}$ \\
\hline $\begin{array}{l}\text { 6. How can people know about your } \\
\text { company? }\end{array}$ & $\begin{array}{l}\text { 6. How was your experience with the } \\
\text { products of the company? }\end{array}$ \\
\hline $\begin{array}{l}\text { 7. What is the strengthens of the company? } \\
\text { 7. What are the main features do you look } \\
\text { in this product/ services? }\end{array}$ \\
\hline $\begin{array}{l}\text { 8. Can you tell us what your target market } \\
\text { and which market segment is do you } \\
\text { promote your product and service? }\end{array}$ & $\begin{array}{l}\text { 8. What part of the company products and } \\
\text { services that make you happy? }\end{array}$ \\
\hline $\begin{array}{l}\text { 9. What are the problems you faced during } \\
\text { product / service marketing and } \\
\text { promotion? }\end{array}$ & $\begin{array}{l}\text { 9. What are the negatives of the products/ } \\
\text { services? }\end{array}$ \\
\hline & $\begin{array}{l}\text { 10. Will you recommend the company } \\
\text { products and services to others? }\end{array}$ \\
$\begin{array}{l}11 . \text { Based on your opinion, what can the } \\
\text { company do better to serve the customer } \\
\text { need? }\end{array}$ \\
\hline
\end{tabular}

Table 3) Codes and Summary

\begin{tabular}{|c|c|}
\hline Codes & Summary \\
\hline $\begin{array}{l}\text { Theme 1: About of } \\
\text { the company }\end{array}$ & $\begin{array}{l}\text { This theme gives details about the company } \\
\text { background. The ambition of GG company is to be an outstanding }\end{array}$ \\
\hline Company & supplier in both audio visual and multimedia systems in Malaysia. \\
\hline Background & $\begin{array}{l}\text { The vision of the company is 'To be Malaysia's Top } 10 \text { Integrated } \\
\text { Audio Visual and Multimedia System Providers in Asia, becoming a } \\
\text { progressive and development nation in future'. Their mission is to } \\
\text { create a customer trust brand and implement strategic control in } \\
\text { pursuit of customer satisfaction, excel and prosper in the industry } \\
\text { with a strategic alliance via smart partnership }\end{array}$ \\
\hline $\begin{array}{l}\text { - Product } \\
\text { and service }\end{array}$ & $\begin{array}{l}\text { The nature of the company's work is supplying, } \\
\text { delivering, installation, testing and commissioning, repair and } \\
\text { service, maintenance contract based and rental. The company also } \\
\text { provides the high quality of product supplied to the customers. }\end{array}$ \\
\hline $\begin{array}{l}\text { Strength } \\
\text { of the company }\end{array}$ & $\begin{array}{l}\text { The reason customers repeat purchased items or } \\
\text { services with } \mathrm{GMBH} \text { is because their products are very durable, } \\
\text { quality and offer the best service to the customers. In short, a }\end{array}$ \\
\hline
\end{tabular}


- $\quad$ Customer satisfaction

- $\quad$ Company achievement

worthwhile price for its quality. In terms of service aspect, most of the customers were very happy with GG's employees because they were very punctual and friendly. Instead of that, the company also helps the customer by recommending the best product available at GG company that fit the customers' needs.

- $\quad$ According to their existing customer, Mr. S also points out that providing good service to the customer is the part of the company's ideology which makes him happy and satisfied. This includes the fast responding or reply and good acting with review that is reported by the customer. Another existing customer is Madam F and Mr. SH. She only purchased one GG's products. However, the product still can be used without any problems and commented that she was very satisfied with the quality of products and service that GG company provided and he also said that he was impressed with the company's service and recommended that the quality product of GMBH was suitable with the customer's budget.

- $\quad$ There are a few sales achievements by the company such as, Twin Tower Petronas KLCC office, SIRIM Malaysia, selected Toyota branch showroom in Malaysia, Prime Minister's office, Putrajaya and others. However, every business has their own challenges. The major challenges faced by GG company. there is a shortage of skilled staff including the difficulty of hiring the right and trained workers. GG company created the solution by appointing a good human resources consultant to manage and handle the employees. One of the successful achievements gained by GG company is successfully creating programs for prospective hires and current employees to improve their workplace satisfaction and work inspiration

Theme 2: Problem identification

\section{$\bullet$} issues

$\bullet$ issues
Employee challenges currently facing the company. For example, in the marketing department. The company has not been able to find the right person for the right position. They also have difficulty hiring people to train the employees. Majority of the employees have poor motivation and poor work satisfaction. As stated by Mr. S, the company has a weak brand image. GG company does not make a strong brand image to the company

Marketing - Based on the interview with the top management, they admitted that their company has a very poor marketing strategy. For example, GG company has developed a website page but has not provided any sales and procurement process. GG company did not know how to explore more about the website. Only pictures and prices of the goods were offered on the website page. GG company has less committed to marketing their products and services using social media platforms such as Facebook and other online platforms. 


\begin{tabular}{|c|c|}
\hline $\begin{array}{l}\text { Theme 3: } \\
\text { Recommendation } \\
\text { - Opinion } \\
\text { from customers }\end{array}$ & $\begin{array}{l}\text { - As stated previously by Mr. S, GG company should } \\
\text { increase their marketing strategy to attract new customers for } \\
\text { example by providing company's uniform for the employees and } \\
\text { this will help in increasing the awareness among the new } \\
\text { customers. Mr. SH also suggested the company to appoint a good } \\
\text { marketing consultant that can help to boost the marketing strategy. }\end{array}$ \\
\hline & erventio \\
\hline $\begin{array}{l}\text { Strategy } \\
\text { strategy }\end{array}$ & $\begin{array}{l}\text { help to overcome GG's problem. There are three interventions that } \\
\text { have been suggested to the company. First, Marketing strategy. } \\
\text { Few suggestions had been ruled out to the company in increasing } \\
\text { the brand awareness by using social media platforms, including } \\
\text { Facebook. }\end{array}$ \\
\hline ur & $\begin{array}{l}\text { The brand image. The company agreed to create } \\
\text { uniforms for their employees. From that, people will recognize and } \\
\text { know more about the company through the uniform. }\end{array}$ \\
\hline $\begin{array}{l}\text { Marl } \\
\text { cons }\end{array}$ & $\begin{array}{l}\text { d marketing consultant in increasing } \\
\text { company decided to implement the } \\
\text { rand awareness by using social media } \\
\text { or their employees to build their brand }\end{array}$ \\
\hline
\end{tabular}

\section{Quantitative Analysis}

Summary for Cycle 1

Table 4: Result of t-test survey (paired) for Section B

\begin{tabular}{|c|c|c|c|c|c|c|c|c|c|}
\hline $\begin{array}{c}\text { Pre t-test and } \\
\text { Post t-test } \\
\text { survey } \\
\text { (Paired) }\end{array}$ & $\begin{array}{c}\text { Mean pre } \\
\text { test }\end{array}$ & SD & $\begin{array}{c}\text { Mean Post } \\
\text { test }\end{array}$ & SD & $\begin{array}{c}\text { Mean pre and } \\
\text { post test }\end{array}$ & SD & $\mathbf{t}$ & df & $\begin{array}{c}\text { Sig. } \\
\text { (2- } \\
\text { tailed) }\end{array}$ \\
\hline Question B1 & 2.05 & 1.0 & 4.08 & 1.1 & -1.583 & 1.544 & -7.945 & 59 & .000 \\
\hline Question B2 & 2.23 & 1.1 & 4.22 & 1.0 & -1.983 & 1.455 & -10.55 & 59 & .000 \\
\hline Question B3 & 2.15 & 1.0 & 4.08 & 1.1 & -1.933 & 1.656 & -9.045 & 59 & .000 \\
\hline Question B4 & 2.05 & 1.0 & 4.15 & 1.2 & -2.000 & 1.657 & -9.349 & 59 & .000 \\
\hline Question B5 & 1.98 & 0.9 & 4.05 & 1.2 & -2.067 & 1.561 & -10.256 & 59 & .000 \\
\hline Question B6 & 2.02 & 1.0 & 4.22 & 1.0 & -2.200 & 1.624 & -10.439 & 59 & .000 \\
\hline Question B7 & 2.13 & 1.0 & 4.12 & 1.1 & -1.983 & 1.578 & -9.733 & 59 & .000 \\
\hline Question B8 & 2.20 & 1.0 & 4.18 & 1.0 & 1.983 & 1.455 & -10.555 & 59 & .000 \\
\hline
\end{tabular}

Overall result finding for Section B showed a negative value for mean and t statistics analysis. The negative value in mean is due to the difference of pre-and post- test while negative value in $T$ statistic indicates the value lies to the left of the mean and the reversal in the directionality of effect which has no bearing on the significance difference between two groups. The paired t-test finding also showed a very significant difference between pre-and post-test $(p=<0.0001)$. Therefore, this finding rejected the null hypothesis (Ho1). This finding also showed the efficiency of the intervention method in pre-and post-test. This finding is also equal to the finding that was observed in the previous finding, the frequency and mean results. The summarized of paired t test findings was tabulated at Table 4. 
Table 5: Result of t-test survey (paired) for Section C

\begin{tabular}{|c|c|c|c|c|c|c|c|c|c|}
\hline $\begin{array}{c}\text { Pre t-test } \\
\text { and Post t- } \\
\text { test survey } \\
\text { (Paired) }\end{array}$ & $\begin{array}{c}\text { Mean } \\
\text { pre test }\end{array}$ & SD & $\begin{array}{c}\text { Mean } \\
\text { post test }\end{array}$ & SD & $\begin{array}{c}\text { Mean } \\
\text { for pre } \\
\text { and post } \\
\text { test }\end{array}$ & SD & t & df & $\begin{array}{c}\text { Sig. } \\
\text { (2-tailed) }\end{array}$ \\
\hline Question C1 & 2.32 & 0.8 & 4.19 & 0.9 & -1.864 & 1.395 & -10.264 & 58 & .000 \\
\hline Question C2 & 2.55 & 0.9 & 4.32 & 0.9 & -1.746 & 1.372 & -9.773 & 58 & .000 \\
\hline Question C3 & 2.12 & 0.9 & 4.17 & 0.9 & -2.034 & 1.189 & -13.144 & 58 & .000 \\
\hline Question C4 & 2.18 & 1.0 & 4.15 & 1.0 & -1.949 & 1.490 & -10.045 & 58 & .000 \\
\hline Question C5 & 2.20 & 1.0 & 4.15 & 0.9 & -1.983 & 1.526 & -9.985 & 58 & .000 \\
\hline
\end{tabular}

Overall, in line with the finding observed in section B, all statements in section $C$ shows a negative value of both mean and T statistics. Table 5 showed the summarized paired test analysis for section $\mathrm{C}$. However, out of 60 respondents, one respondent did not answer the statement or question in section $C$. This is maybe due to the shortage of time, or the respondent did not fully aware of the existence of this section. Lastly, there is no need to compare the result of this section because in section $D$, it is only measured after the intervention is implemented.

\section{Summary for Cycle 2}

The previous post survey questionnaire has been conducted to the existing customer and has been analysed by using T-test (SPSS). The descriptive analysis was used to summarize the demographic profile of 100 from the Cycle 2 group. The overall of the result shows that there is no difference between both groups (Cycle 1 and Cycle 2).

\section{Discussion}

\section{Reflection}

Research Objective 1: To identify the issues related to the brand awareness of the company's products among its potential and existing customers'

Objective 1 is 'To identify the issues related to the brand awareness of the company's products among its potential and existing customers'. The research investigated the problems faced by GG company. Throughout the interview session with the management and existing customers, it was discovered that the absence of the marketing strategies and the customers were difficult to recognize the company brand. Based on Table 3, NVivo software is used to evaluate and categorize the themes based on the interview session. There are four (4) themes, and ten (10) sub themes from five (5) scripts that had been analysed. As a result, the problem diagnosis from the interview session and from the survey was proposed with an intervention plan which is to increase the brand awareness among the customers.

Research Objective 2: To implement the intervention to increase the brand awareness of the company's products.

Following that, to analyse the second objective in this research, post- questionnaire survey from Cycle 1 was utilized and distributed to the 100 responders ( 80 percent of existing customer and 20 percent of new potential customers). The proposed method will be used to assess client awareness toward the image of the company. The data survey was gathered and analysed for GG company. The method is by utilizing the T-test to determine the effectiveness 
of the intervention from existing and new potential customers. Table 6 below: Summary of the T-test result.

\begin{tabular}{lcc}
\hline Hypothesis & Result & Significant \\
\hline H0: There is no difference/ & $p$-Value $=>0.001$ & \\
affect before and after the & & No \\
intervention & & \\
\hline
\end{tabular}

The T-test and $p$-Value (>0.001), show insignificant results based on the results provided in Table 7.2.2. There is no difference between two groups (Cycle 1 and Cycle 2) when the intervention was implemented in GMBH Sdn Bhd, as shown in Tables 6.5.2B, 6.5.4C, and 6.5.6D. Thus, for the result, the null hypothesis was accepted because no changes between the two groups were detected (Cycle 1 and Cycle 2). The results of both sets' observations are nearly identical. In other words, by implement the interventions, both groups are more aware of the company.

Research Objective 3: To recommend a marketing plan to increase brand awareness of the company's products.

In Cycle 2 of Action Research, the second intervention was suggested to the GG company, and the company successfully adopted the intervention. GG company is looking for a skilled consultant to help them overcome their awareness issues. Consultant is a competent advisor who analyses and provides recommendations for creating value for their customers, according to research done by (Brämming, 2017). A consultant can help with the development thorough communication strategy, the identification of a company's marketing message, and the selection of the appropriate marketing mix to reach the target market. After the company engaged with candidate as a marketing consultant, company will conduct one-on-one interview. The goal of the interview with the marketing consultant is to learn about the marketing strategy for the company to raise client awareness. Hiring a good marketing consultant, on the other hand, will be incredibly useful to the GG company. We noticed various recommended proposals planned by the marketing consultant throughout the interview, particularly amid this Covid-19 pandemic:

- $\quad$ Run Facebook Ads

- Improve Search engine optimization (SEO)

- Improve the marketing content in social media

- $\quad$ Partner with influencers to review the company brand

- Incorporate charities campaign due to current pandemic issue

\section{Conclusion \\ Contribution}

The present study makes an important theoretical contribution to the body of information in the field of brand awareness. The research contributes to the vital knowledge in the field of marketing, targeted to brand awareness especially in Malaysian context. As refer to previous literature studies in the field of CSR, the majority of the studies are applied studies, with just a few studies using the Action Research method and as a result, this study fills a gap in the action research literature in the field of brand awareness. The research also adds to the body of knowledge on brand awareness in the audio-visual and multimedia industries. 
The research helped to raise the company's brand image among new and current customers. By conducting this research can also, assist the company in understanding brand awareness techniques, as the company has agreed to introduce the intervention from Cycle 1 and Cycle 2 and to assist the GG company in increasing their brand awareness.

\section{Action Research Reflection}

\section{Research Process Reflection}

Cycle 2 was the only time a post-survey was performed. The aim of this action research is to determine consumer brand awareness of the company, which will help in the formulation of an effective intervention. The T-test and $p$-Value $(>0.001)$ values for Cycle 2 are negligible. The marketing consultant has developed strategies to raise awareness of the GG company business in the future, as discussed in Objective 3.

\section{Research Reporting Effectiveness}

Even though the intervention was only used for a short amount of time, the effectiveness can be seen by comparing before and after outcomes. Cycle 1 interventions have a positive impact on the company's results and raise consumer awareness. There isn't any difference between the outcome in the post-result in Cycle. Although the results from Cycle 2 are similar, (based on the intervention, on the previous finding, the organization developed two new interventions for Cycle 2 that were successfully implemented, namely, "To increase awareness by using the Facebook page" and "To appoint the marketing consultant.". However, the intervention in this study improved most significantly in raising awareness by using a Facebook page. Facebook page awareness has increased between before and after.

\section{Action Research Overall Reflection}

In this action research, the objective of the research was accomplished. The main objective of this study was to identify the issues related to the brand awareness of the company's products among its potential and existing customers and were successfully identified the issued before implement the interventions. After identified the issues, The interventions have been successfully implemented and brought a positive impact into this company.

\section{Overall Conclusion}

The research concluded that there is an improvement in Cycle 1 and Cycle 2 between before and after the intervention. It was determined that the interventions on Cycle had an impact on the company's brand awareness among new potential customers. Although the latest involvement in Cycle 2 had not much impact on the company's brand awareness among the potential customers and existing customers. Each aspect and strategy in Cycle 1, as determined by the study, have given a significant impact on the awareness of the company and there is insignificant impact from both customers. According to the study, it is important to increase brand awareness with well-executive initiative in order to really have a positive impact toward GG company

\section{Limitation}

This study, like most of the academic studies, was subject to some limitations. Regardless of the relevance of the results, the findings should be analysed with caution. Due to the Covid19 pandemic, it was challenging to recruit additional participants, and the questionnaire was generated using an online questionnaire, whereas the interview with the existing customers 
was done by using online platforms such as WhatsApp video call and WebEx platform. It would have been better if the interview was conducted face to face. Another limitation is the duration of the intervention, as it would be better to measure the intervention's efficacy over a prolonged period of the time. In addition, the relatively small size of the sample is another limitation related to data collection. The questionnaire was distributed through online google form which can contribute to the bias in the results because it is difficult to track if the respondents have answered more than one time. There was some missing data because some of the respondents did not answer all the questions provided in the online questionnaire. The use of this type of method to collect data, through the internet and using an online database, has several advantages such as the geographical and occupational diversification of the respondents (Hishan et.al., 2021; Sanil et.al., 2016; Kelana et.al., 2016). However, it also had other disadvantages, such as the weak representation of the age group, which may contribute to the bias in this study. It is important to collect a balanced sample in the various characterization variables, to allow a more correct and reliable comparison between individuals with different characteristics. Another limitation is the lack of use of images for the brand awareness test. Although the aim is to give people the possibility to verify the brand, because what is being studied is the brand awareness, i.e., if the brand elements are recognized, the respondents had unlimited time to look at the image and recognize the brand.

\section{Future Recommendation}

In this research paper, due to the online spread link of the questionnaire, some of the respondents may not have knowledge about the company or its nature of business, compared to respondents that are more technologically advanced and familiar with the company. Therefore, the moderating effect of age be examined in this study. For future studies, we might need to assess whether similar results are reached for different types of visitors (new and frequent customers). Future research also might need to collect more data through increasing the sample size. This is because larger samples sizes aid in determining the average value of a quality among tested samples, this average is the mean. The larger the sample size, the better. The more precise the mean, the greater. Next, upcoming research also needs to include more images in their questionnaire or survey due to human beings naturally responding well with images to recall the brand or company image. On the other hand, GG company also should focus on social media marketing especially during this COVID-19. Since a substantial majority of GG's customer are likely to be on social media, take advantage of this. Concentrate marketing strategies on social media platforms that drive a large portion of GG's customer involvement, such as Facebook Page or develop new social media like Telegram or Instagram. Instead of focusing solely on making a sale, GG's can create relevant posts that add meaning, education, and entertainment. To overcome these limitations, future research could attempt to combine marketing consultant's perception with direct methods of changes in brand performance, even though it would be difficult performance, even though it would be difficult to distinguish which impact is due to social media. Furthermore, the study conducted a preliminary exploratory analysis of conditions that may lead to increased brand awareness (Sanil et.al, 2015; Qureshi et.al, 2020; Vaicondam et.al, 2021; Ramakrishnan et.al., 2016; Manokaran et.al, 2018). More research is needed to fully understand cause and effect relationships and to investigate the potential significance of other managerial decision that are related to social media usage. Eventually, this study focused only on GG company, and it would be interesting to extend the research to another firm with different nature of business. 


\section{References}

Akhtar, N., Khan, N., Khan, M., Ashraf, S., Hashmi, M. S., Khan, M. M., \& Hishan, S. S. (2021). Post-COVID 19 Tourism: Will Digital Tourism Replace Mass

Tourism?. Sustainability, 13(10), 5352.

Alalwan, A. A. (2018). Investigating the impact of social media advertising features on customer purchase intention. International Journal of Information Management, 42, 65-77.

Alhaddad, A. A. (2015). The effect of advertising awareness on brand equity in social media. International Journal of e-Education, e-Business, e-Management and e- Learning, 5(2), 73.

Alnsour, M., \& Tayeh, Z. A. (2019). Impact of social media use on brand awareness: an applied study on Jordanian banks that uses Facebook. International Journal of Electronic Banking, 1(4), 341-357.

Ansari, S., Ansari, G., Ghori, M. U., \& Kazi, A. G. (2019). Impact of brand awareness and social media content marketing on consumer purchase decision. Journal of Public Value and Administrative Insight, 2(2), 5-10.

Bilgin, Y. (2018). The effect of social media marketing activities on brand awareness, brand image and brand loyalty. Business \& Management Studies: An International Journal, 6(1), 128-148.

Brämming, E., \& Nordin, L. (2017). Finding a Qualified Consultant: A Case Study of Purchasing Practices in the Swedish Public Sector.

Chicago, H. (2021). Raising brand awareness during a pandemic. Retrieved from https://hubbardchicago.com/raising-brand-awareness-during-a- pandemic/

Chierici, R., Del Bosco, B., Mazzucchelli, A., \& Chiacchierini, C. (2019). Enhancing brand awareness, reputation and loyalty: The role of social media. International journal of Business and Management, 14(1), 216-228.

Faladhin, J., \& Martina, D. (2020). Customers' First Impression of a Brand and Its Relation to Their Shopping Experiences. In 2nd Social and Humaniora Research Symposium (SoRes 2019) (pp. 347-352). Atlantis Press. Ghirvu, A. I. (2013). The AIDA model for advergames. The USV Annals of Economics and Public Administration, 13(1 (17)), 90-98.

Horsfall, H. A. R. C. O. U. R. T. (2020). BRAND EQUITY AND PURCHASE INTENTIONS OF TELECOMMUNICATION FIRMS IN RIVERS STATE OF NIGERIA. International Journal of Business \& Law Research 6(4):1-10, Oct.-Dec., 2018

Hassan, S., Nadzim, S. Z. A., \& Shiratuddin, N. (2015). Strategic use of social media for small business based on the AIDA model. Procedia-Social and Behavioral Sciences, 172, 262269.

Hishan, S. S., Qureshi, M. I., Khan, N., Ramakrishnan, S., Jaiprakash, H., \& Vaicondam, Y. (2021). Impact of COVID-19 pandemic on sustainable development goals: What we learn from the past and where we are heading?. Studies of Applied Economics, 39(3).

Jermsittiparsert, K., Sutduean, J., \& Sriyakul, T. (2019). Determinants of Social Media Usage (Face-book) to Create Brand Awareness among Indonesian Consumers. International Journal of Innovation, Creativity and Change, 5(2), 1272-1289.

Johnson, A. P. (2008). A short guide to action research. Allyn and Bacon.

Kelana, B. W. Y., Mansor, N. N. A., \& Sanny, L. (2016). HR sustainability practices instrument comparative analysis in Malaysian SMEs. VOL. 24 (S) JUL. 2016, 73. 
Kilei, P., Iravo, M., \& Omwenga, J. (2016). The impact of Brand Awareness on Market Brand Performance of service Brands: contextual consideration of Kenya" s banking industry. European Journal of Business and Management, 8(10), 92-103.

Donovan, R., \& Henley, N. (2010). Principles and practice of social marketing: an international perspective. Cambridge University Press.

Majid, S. (2019). Message factors that favorably drive consumer's attitudes and behavioral intentions towards social network and media platforms (Doctoral dissertation, University of Plymouth).

Majid, S. (2019). MESSAGE FACTORS THAT FAVOURABLY DRIVE CONSUMER'S ATTITUDES AND BEHAVIOURAL INTENTIONS TOWARDS SOCIAL NETWORK AND MEDIA PLATFORMS (Doctoral dissertation, University of Plymouth). Manokaran, K., Ramakrishnan, S., Hishan, S., \& Soehod, K. (2018). The impact of corporate social responsibility on financial performance: Evidence from Insurance firms. Management Science Letters, 8(9), 913-932.

Pandjaitan, D. H. (2018). An Analysis of Brand Awareness Influence on Purchase Intention in Bandar Lampung City's Online Transportation Service (Study on Y Generation Consumers). KnE Social Sciences.

Panigrahi, S. (n.d.). Benefits of hiring a digital marketing consultant. Retrieved from https://www.consultantsreview.com/news/benefits-of-hiring-a-digital- marketingconsultant-nwid-1235.html

Prathapan, M., Sahadevan, S. D., \& Zakkariya, K. A. (2018). Effectiveness of digital marketing: Tourism websites comparative analytics based on AIDA model. International Journal of Innovative Research \& Studies, 8(4), 262-273.

Qureshi, M. I., Khan, N., Qayyum, S., Malik, S., Sanil, H. S., \& Ramayah, T. (2020). Classifications of sustainable manufacturing practices in ASEAN region: A systematic review and bibliometric analysis of the past decade of research. Sustainability, 12(21), 8950.

Ramakrishnan, S., Hishan, S. S., Shahabuddin, A. S. M., \& Kanjanapathy, M. (2016). The role of corporate social responsibility in flood mitigation among the listed insurance companies in Malaysia. International Review of Management and Marketing, 6(4S).

Retmawan, B. (2020). Perumusan Strategi Bisnis untuk Peningkatan Market Share PT Terminal Teluk Lamong. Business and Finance Journal, 5(1).

Sanil, H. S., Ramakrishnan, S., Alwethainani, M., Kazi, A. G., \& Siddique, M. (2016). Effectiveness of supply chain management with reference to apparel industry: A case study in India. International Review of Management and Marketing, 6(4S).

Sanil, H. S., \& Ramakrishnan, S. (2015). Communicating the corporate social responsibility on the company website: A study conducted on WRAP certified apparel manufacturers in India. International Journal of Economics and Financial Issues, 5(1S).

Shahatha Al-Mashhadani, A. F., Qureshi, M. I., Hishan, S. S., Md Saad, M. S., Vaicondam, Y., \& Khan, N. (2021). Towards the Development of Digital Manufacturing Ecosystems for Sustainable Performance: Learning from the Past Two Decades of Research. Energies, 14(10), 2945.

Hishan, S. S., Ramakrishnan, S., Rahim, R., Te Chuan, L., Mahmood, A., \& Beri, N. (2021). Understanding disaster risk and development of resilience as one of the fundamental drivers of sustainable development in India with special reference to supercyclone Amphan. International Journal of Disaster Risk Reduction, 102339.

Tonkin-Crine, S., Anthierens, S., Hood, K., Yardley, L., Cals, J. W., Francis, N. A., ... \& Little, P. (2015). Discrepancies between qualitative and quantitative evaluation of randomised 
controlled trial results: achieving clarity through mixed methods triangulation. Implementation Science, 11(1), 1-8.

Torten, R. J. (2018). A quantitative regression study of the impact of security awareness on information technology professionals' desktop security behavior (Doctoral dissertation, Capella University).

Vaicondam, Y., Hishan, S. S., Begum, S., \& Hassan, M. (2021). Information and Communication Technology-Based Education Planning and Attitude of College Students. International Journal of Interactive Mobile Technologies, 15(4).

Wiggins, C. (2020). Content Marketing: An Action Research Approach to Developing a Customer Engagement Strategy (Doctoral dissertation, The University of Liverpool (United Kingdom).

Zaif, A. (2016). The Impact of Brand Awareness on Companies Marketing Strategies. Risk in Contemporary Economy, 213-219. 